\title{
FORMULATION AND EVALUATION OF ANTIBACTERIAL AND ANTIOXIDANT POLYHERBAL LOTION
}

\section{Rajendra Gyawali, Nira Paudel, Sahana Shrestha, and Ashok Silwal}

Journal of Institute of Science and Technology

Volume 21, Issue 1, August 2016

ISSN: 2469-9062 (print), 2467-9240(e)

Editors:

Prof. Dr. Kumar Sapkota

Prof. Dr. Armila Rajbhandari

Assoc. Prof. Dr. Gopi Chandra Kaphle

JIST, 21 (1), 148-156 (2016)

Published by:

Institute of Science and Technology

Tribhuvan University

Kirtipur, Kathmandu, Nepal

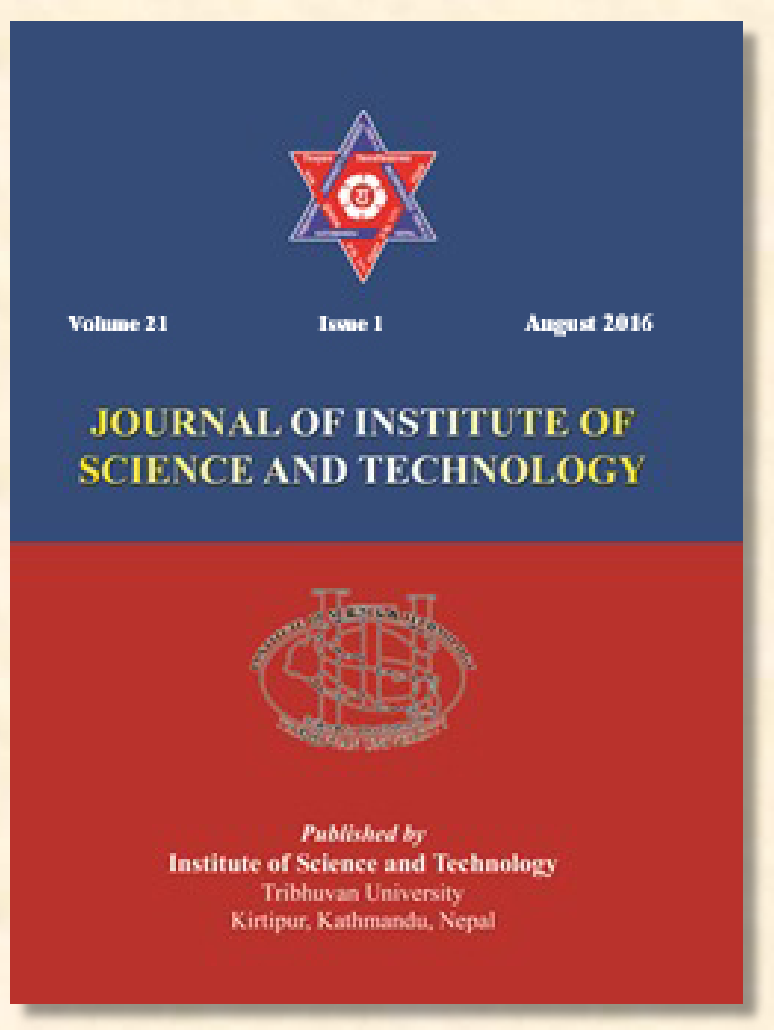




\title{
FORMULATION AND EVALUATION OF ANTIBACTERIAL AND ANTIOXIDANT POLYHERBAL LOTION
}

\author{
Rajendra Gyawali*, Nira Paudel, Sahana Shrestha, and Ashok Silwal \\ Kathmandu University, Department of Pharmacy, Dhulikhel, Nepal \\ *Corresponding email: gyawali@ku.edu.np
}

\begin{abstract}
There is increased scientific evidence that plants possess a vast and complex arsenal of active ingredients which have the ability to calm or smooth the skin as well as restore actively, heal and protect the skin. The present work deals with the development and evaluation of the poly herbal lotion containing Trigonella foenum-graecum, Citrus lemon, Matricaria chamomilla and Cymbopogon citrates. Different types of formulations oil in water $(\mathrm{O} / \mathrm{W})$ herbal lotions namely $\mathrm{F} 1$ to $\mathrm{F} 13$ were formulated by incorporating different concentrations of stearic acid and Triethanolamine. Formulation of Triethanolamine and stearic acid was optimized as 2.52:9.35. The prepared lotion was evaluated for its antimicrobial, antioxidant and pharmaceutical parameters. The lotion formulation showed no redness, edema, inflammation and irritation during sensitivity test indication that it is safe to use. Stability studies of the lotion showed that the lotion was stable after three months.
\end{abstract}

Key Words: Herbal formulation, Triethanolamine, Stearic acid, Antioxidant, Antibacterial

\section{INTRODUCTION}

Herbal extracts are primarily added to cosmetic preparations due to several associated properties such as antioxidant, antibacterial and antiinflammatory properties. The lotion as topical suspensions, solutions and emulsions are usually serve as vehicles for topically applied drugs, as emollients, or as protective or occlusive dressings, or they may be applied to the skin and membranes such as the rectal, buccal, nasal, and vaginal mucosa, urethral membrane, external ear lining, or the cornea (Idson \& Lazarus 1987, Buhse et al. 2005). But the serious problems associated with the formulation and manufacture of topical-mucosal preparations is the establishment of reliable techniques for their characterization, mainly because of the complexity of their physical structure (Tamburic et al. 1996).

Herbal remedies enrich the body with nutrients and other useful minerals. There is increased scientific evidence that plants possess a vast and complex arsenal of active ingredients which not only have the ability to calm or smooth the skin but also to restore actively, heal and protect the skin (Gediya et al. 2011, Shivanand et al. 2010). An herbal lotion that can give effective protection to skin and free from any toxicity or toxic residue or irritation when regularly used should be cosmetically acceptable.
The objective of the present paper was development of formulation of lotion from herbal extracts and their evaluation.

\section{MATERIALS AND METHODS}

\section{Plant materials}

The medicinal plants Allium sativum, Trigonella foenum-graecum, Citrus lemon, Matricaria chamomilla and Cymbopogon citrates were collected from the local market of Kathmandu. The bulbs of Allium sativum, seeds of foenum-graecum were sun dried for seven days. After drying the plants were crushed in powder. The Citrus lemon was squeezed to obtain the juice. The plants were identified at Department of Pharmacy, Kathmandu University, Nepal. Herbal specimen was deposited at the Department of Pharmacy, Kathmandu University. The essential oils of Matricaria chamomilla and Cymbopogon citrates were obtained as a gift sample from Herbs Production and Processing Co. Ltd Nepal.

\section{Preparation of extracts}

About $500 \mathrm{~g}$ of dried powder of plant was extracted in ethanol for seven days with frequent agitation. The extraction process was carried out three times with the same sample. The filtrates were collected and evaporated in a water bath. Lemon juice obtained by squeezing was further concentrated in water bath. 


\section{Phytochemical screening}

Phytochemical screening of all extracts was carried out according to standard method (Trease \& Evans 1989). The extracts were analyzed for presence of alkaloids, carbohydrates, glycosides, saponin, phytosterol, phenols, tannins and flavonoids.

\section{Antibacterial property}

Antibacterial property was evaluated by well diffusion method (Collins et. al 1995). The microorganisms used were Staphylococcus aureus, Pseudomonas aeruginosa, Escherichia coli and Klebsiella pneumonia. Total $20 \mu \mathrm{l}$ of test solutions of the sample and standard prepared $(2 \%, 4 \%$, and $6 \%)$ were then pipetted with the help of the micropipette and poured in the prepared bore in each nutrient agar plate swabbed with different bacteria with great care. Similarly, $20 \mu \mathrm{l}$ of DMSO (10\%) solution was also poured in another bore as control. The nutrient agar plates were allowed to stand for about 1 hour till the test solution completely diffuses in the media. The plates were then incubated at the temperature of $37^{\circ} \mathrm{C}$ for 48 hours. After 48 hours, zone of inhibition was measured (Junaid et al. 2006). Minimum Inhibitory Concentration (MIC) test was carried out by serial dilution method (Mhatre et al. 2014). The extracts and EO were serially diluted to obtain the concentration from $200 \mathrm{mg} / \mathrm{ml}$ to $6.25 \mathrm{mg} / \mathrm{ml}$. A loop full of microbial suspension which was already prepared was added to each test tube. The test tubes were then incubated at $37^{\circ} \mathrm{C}$ for 24 hours. The MIC is the concentration of the highest dilution tube in which the bacterial growth was absent, hence no turbidity observed.

\section{Determination of DPPH free-radical scavenging activity}

The antioxidant activity of the extracts and the essential oil based on the scavenging activity of the stable 1, 1-diphenyl-2-picrylhydrazyl (DPPH) free radical was determined by the method described by Mensor et al. (2001) with a slight modification. In the DPPH radical scavenging assay, antioxidants react with DPPH, and convert it to the yellow colored a, a-diphenyl- $\beta$-picryl hydrazine. Ascorbic acid was used as standard.

The DPPH radical scavenging activity percentage was calculated by using the formula:

DPPH radical scavenging activity $(\%)=\left(\mathrm{A}_{\text {control}^{-}}\right.$ $\left.\mathrm{A}_{\text {sample }}\right) / \mathrm{A}_{\text {control }} \times 100$

Where, $\mathrm{A}_{\text {control }}$ is the absorbance of a DPPH solution without sample, and $A_{\text {sample }}$ is the absorbance of the sample.

\section{Formulation of lotion}

Topical lotion formulation was designed using central composite design (CCD) with two factor and 3 levels. Stearic acid and Triethanolamine were chosen as independent variables while spreadability, $\mathrm{pH}$ and viscosity as dependent factors. The lotion was prepared by adding non-polar phase to the polar phase with rapid stirring to avoid separation of water and oil phase. Non-polar phase was first melted together and slowly added to the preheated mixture of polar phase. Triethanolamine and stearic acid when mixed, undergo an acid-base reaction to yield an ionic compound (a salt). This salt has a nonpolar section and a charged section, so it is a good emulsifying agent. Cetosteryl alcohol in combination with other ingredients in the formulation such as Triethanolamine and stearic acid forms an emulsion. This stops oil and water from separating.

\section{Statistical analysis}

Mathematical relationships for the measured dependent variable (response) and the independent variables were developed using statistical software Minitab. Thirteen tests were conducted as per the software. The three output variables (responses), such as viscosity (Y1), $\mathrm{pH}$ (Y2), spreadability (Y3), were evaluated. The experimental results were fitted to a polynomial quadratic model by applying multiple regression analysis for $\mathrm{pH}$, viscosity and spreadability. The effect of formulation variables on different dependent or response variables was assessed by the generated regression coefficients and $r^{2}$ values. The fitted quadratic equations relating the responses such as viscosity (Y1), $\mathrm{pH}$ (Y2), spreadability (Y3), to the transformed factor are given in equations respectively below:

$\mathrm{Y}_{1}=+5656.6-101.1 \mathrm{X}_{1}+1755.8 \mathrm{X}_{2}-365.7 \mathrm{X}_{1} \mathrm{X}_{2}+$ $374.8 \mathrm{X}_{1}^{2}+872.8 \mathrm{X}_{2}^{2}$

$\mathrm{Y}_{2}=+5.77400+0.64897 \mathrm{X}_{1}-0.21598 \mathrm{X}_{2}-0.17750$ $\mathrm{X}_{1} \mathrm{X}_{2}-0.10613 \mathrm{X}_{1}^{2}-0.02388 \mathrm{X}_{2}^{2}$

$\mathrm{Y}_{3}=+9.64+0.00214 \mathrm{X}_{1}-0.78373 \mathrm{X}_{2}-0.32000 \mathrm{X}_{1}^{2}$ $0.14500 \mathrm{X}_{2}^{2}-0.02500 \mathrm{X}_{1} \mathrm{X}_{2}$

Where; $\mathrm{X}_{1}$ is concentration of Triethanolamine, $\mathrm{X}_{2}$ is the concentration of stearic acid.

\section{Optimization of Formulation}

The formulation was optimized using response optimizer in Minitab Software. The excipients used as variables were Triethanolamine and Stearic acid. Desirability function was calculated for $\mathrm{pH}$ (Y1), viscosity (Y2), and spreadability (Y3) using the software. On the basis of the ratio obtained from 
the software final optimized formulation was developed.

\section{Evaluation of Pharmaceutical parameters of lotion}

Preliminary Pharmaceutical evaluation of lotion formulations was carried out as follows:

PH: Lotion $\mathrm{pH}$ was measured with a digital $\mathrm{pH}$ meter. $10 \%$ solution of lotion was prepared and the solution was immersed in the $\mathrm{pH}$ meter and the measured $\mathrm{pH}$ was recorded (Namita \& Nimisha 2013).

Viscosity: viscosity was evaluated in Brookfield viscometer using LV-64 spindle. The rotation rate was adjusted to $25 \mathrm{RPM}$. The formulated lotion was directly immersed into the spindle and the viscosity was measured (Kumar et al. 2011, Neuwald 1966).

Spreadability: The spreadability of lotion was determined by the parallel plate method. Two glass slides of 20/20 cm were selected. About $1 \mathrm{~g}$ of the lotion formulation was placed over one of the slides. The other slide was placed upon the top of the lotion such that the lotion was sandwiched between the slides and $125 \mathrm{~g}$ weight was placed upon the upper slide so that lotion between the two slides was pressed uniformly to form a thin layer. The weight was removed and the spread diameter was measured (Garg et al. 2002).

Stability Test: The formulated lotion was stored at different temperatures and humidity conditions of $25 \pm 2{ }^{\circ} \mathrm{C} / 60 \pm 5 \% \mathrm{RH}$ (at room temperature), $40 \pm 2$ ${ }^{\circ} \mathrm{C} / 75 \pm 5 \% \mathrm{RH}$ (accelerated temperature) for a period of three months and studied for $\mathrm{pH}$, viscosity and spreadability (Negi et al. 2012).

Sensitivity Test: A portion of lotion was applied on the forearms of 6 volunteers and left for 20 minutes. After 20 minutes any kind of irritation if occurred was noted (Draize et al. 1944).

Washability Test: A portion of lotion was applied over the skin of hand and allowed to flow under the force of flowing tap water for 10 minutes. The time when the lotion completely removed was noted.

Appearance: The color, odor and homogeneity of the lotion were visually determined.

Type of emulsion test: Dye solubility and dilution test was conducted to determine the type of emulsion formed (Tharwat 2013).

\section{RESULTS AND DISCUSSION}

\section{Phytochemical screening}

The plants were undertaken for phytochemical screening of alkaloids, carbohydrates, glycosides, saponins, phytosterols, phenols, tannins, flavonoids. It was investigated that tannin, phenols and phytosterols were commonly found. Alkaloid was absent in Allium sativum and Citrus lemon. Carbohydrate and glycosides were absent in all samples. Flavonoids, exhibits the large number of biological activities like anti-inflammatory, antioxidant and antimicrobial properties (Ojala, 2000).

\section{Antibacterial activity study}

Ethanol extract of the plants were undertaken for antibacterial activity. All of the extracts showed significant antibacterial activity at 6 percent concentration. Among five extracts Allium sativum showed less activity against bacteria while Citrus lemon showed highest activity. Afterwards, five different formulations were prepared using four of the five plant extract excluding Allium sativum since it possesses minimum antibacterial activity.

Table 1. Zone of inhibition of plant extracts against different bacteria

\begin{tabular}{|c|c|c|c|c|c|}
\hline \multirow{3}{*}{ Extract } & \multicolumn{5}{|c|}{ Zone of inhibition (mm) } \\
\cline { 2 - 6 } & $\begin{array}{c}\text { Concentration } \\
(\%)\end{array}$ & $\begin{array}{c}\text { Staphylococcus } \\
\text { aureus }\end{array}$ & $\begin{array}{c}\text { Pseudomonas } \\
\text { aeruginosa }\end{array}$ & $\begin{array}{c}\text { Escherichia } \\
\text { coli }\end{array}$ & $\begin{array}{c}\text { Klebsiella } \\
\text { pneumoniae }\end{array}$ \\
\hline \multirow{3}{*}{ Allium sativum } & 2 & $5.66 \pm 1.52$ & $6.66 \pm 0.58$ & $5.66 \pm 0.58$ & $4.33 \pm 0.58$ \\
\cline { 2 - 6 } & 4 & $8.66 \pm 1.52$ & $9.33 \pm 1.15$ & $8 \pm 1$ & $7.33 \pm 1.52$ \\
\cline { 2 - 6 } & 6 & $9.66 \pm 1.52$ & $11 \pm 1$ & $10.66 \pm 0.58$ & $10 \pm 1$ \\
\hline \multirow{3}{*}{$\begin{array}{c}\text { Trigonella foenum } \\
\text { graceum }\end{array}$} & 2 & $15 \pm 1$ & $14.66 \pm 0.58$ & $14.33 \pm 1.52$ & $12 \pm 1$ \\
\cline { 2 - 6 } & 4 & $17.33 \pm 0.58$ & $17.33 \pm 1.15$ & $16 \pm 1$ & $15.33 \pm 1.52$ \\
\hline & 6 & $20.66 \pm 0.58$ & $19 \pm 1$ & $19 \pm 1$ & $18.66 \pm 0.58$ \\
\hline & 2 & $14.66 \pm 1.52$ & $17 \pm 2$ & $17.33 \pm 1.15$ & $18.33 \pm 1.52$ \\
\hline
\end{tabular}




\begin{tabular}{|c|c|c|c|c|c|}
\hline Citrus lemon & 4 & $20 \pm 1$ & $20 \pm 1$ & $20 \pm 1$ & $19.33 \pm 1.52$ \\
\cline { 2 - 6 } & 6 & $21 \pm 1$ & $22 \pm 1$ & $21 \pm 1$ & $21.33 \pm 1.52$ \\
\hline \multirow{3}{*}{$\begin{array}{c}\text { Matricaria } \\
\text { chamomilla }\end{array}$} & 2 & $13.66 \pm 1.52$ & $13 \pm 1$ & $12.66 \pm 1.15$ & $12 \pm 1$ \\
\cline { 2 - 6 } & 4 & $17.33 \pm 1.15$ & $19.33 \pm 1.52$ & $14.66 \pm 1.52$ & $14.66 \pm 0.58$ \\
\hline \multirow{3}{*}{$\begin{array}{c}\text { Cymbopogon } \\
\text { citrates }\end{array}$} & 6 & $21.33 \pm 1.52$ & $22 \pm 1$ & $18 \pm 1$ & $19.33 \pm 1.52$ \\
\cline { 2 - 6 } & 4 & $15.33 \pm 2.08$ & $16 \pm 1$ & $13.66 \pm 1.15$ & $13.66 \pm 1.52$ \\
\hline Standard cipro & 6 & $18.66 \pm 0.58$ & $17.33 \pm 0.58$ & $17 \pm 1$ & $17.33 \pm 0.58$ \\
\hline Standard Amox & 6 & $22.33 \pm 2.08$ & $22.33 \pm 1.52$ & $20 \pm 1$ & $19.66 \pm 1.15$ \\
\hline
\end{tabular}

Among the five different combination of extracts, ratio 2 (R2) showed good antibacterial property as compared to remaining others. Since R2 combination shows highest antibacterial activity, same was used for lotion preparation.

Table 2. Zone of inhibition of ratios of extracts against different bacteria

\begin{tabular}{|c|c|c|c|c|c|c|c|}
\hline Microorganisms & $\mathbf{R} 1$ & $\mathbf{R 2}$ & $\mathbf{R 3}$ & $\mathbf{R 4}$ & $\mathbf{R 5}$ & Std. Cipro & Std. Amox \\
\hline $\begin{array}{l}\text { Staphylococcus } \\
\text { aureus }\end{array}$ & $18 \pm 1$ & $\begin{array}{l}20.66 \pm \\
1.15\end{array}$ & $\begin{array}{l}17.33 \pm \\
1.15\end{array}$ & $\begin{array}{l}15.33 \pm \\
0.58\end{array}$ & $\begin{array}{l}15.66 \pm \\
0.58\end{array}$ & $25 \pm 1$ & $26 \pm 1$ \\
\hline $\begin{array}{l}\text { Pseudomonas } \\
\text { aeruginosa }\end{array}$ & $\begin{array}{l}16.33 \pm \\
0.58\end{array}$ & $\begin{array}{l}20.66 \pm \\
0.58\end{array}$ & $\begin{array}{l}15.66 \pm \\
0.58\end{array}$ & $\begin{array}{l}16.33 \pm \\
0.58\end{array}$ & $\begin{array}{l}12.66 \pm \\
0.58\end{array}$ & $25 \pm 1$ & $26 \pm 1$ \\
\hline Escherichia coli & $\begin{array}{l}14.33 \pm \\
0.58\end{array}$ & $\begin{array}{l}18.66 \pm \\
1.53\end{array}$ & $16 \pm 1$ & $13 \pm 1$ & $15 \pm 1$ & $25.66 \pm 1.15$ & $25.66 \pm 2.08$ \\
\hline $\begin{array}{l}\text { Klebsiella } \\
\text { pneumoniae }\end{array}$ & $14 \pm 1$ & $\begin{array}{l}16.33 \pm \\
1.15\end{array}$ & $\begin{array}{l}14.66 \pm \\
1.53\end{array}$ & $12 \pm 1$ & $\begin{array}{l}12.33 \pm \\
0.58\end{array}$ & $24.66 \pm 1.15$ & $26.66 \pm 1.15$ \\
\hline
\end{tabular}

$R 1=1: 1: 1: 1 ; R 2=1: 1: 1: 2 ; R 3=2: 1: 1: 1 ; R 4=1: 2: 1: 1 ; R 5=1: 1: 2: 1$ (Trigonella graecum foenum: Citrus lemon: Matricaria chamomilla: Cymbopogon citratus).

Table 3. Antibacterial activity of final formulation compared to the marketed product.

\begin{tabular}{|l|l|l|}
\hline \multicolumn{2}{|c|}{ Zone of Inhibition (mm) of final formulation (F2) } \\
\hline Microorganisms & Formulation & Std. \\
\hline Staphylococcus aureus & $20 \pm 1$ & $23.33 \pm 0.57$ \\
\hline Pseudomonas aeruginosa & $19.33 \pm 1.53$ & $22.33 \pm 2.08$ \\
\hline Escherichia coli & $17.33 \pm 0.58$ & $22.66 \pm 1.15$ \\
\hline Klebsiella pneumoniae & $16.33 \pm 1.52$ & $22.66 \pm 0.58$ \\
\hline
\end{tabular}

\section{Antioxidant activity test}

The antioxidant activity of the extracts, oils and final product was evaluated. The antioxidant property of the formulation was significant as compared to the standard Ascorbic acid. The $\mathrm{IC}_{50}$ value of Ascorbic acid was $4.8225 \mu \mathrm{g} / \mathrm{ml}$, while R2 formulation was
$10.8921 \mu \mathrm{g} / \mathrm{ml}$. Among extracts and essential oils Cymbopogon citrates has maximum antioxidant property with $\mathrm{IC}_{50}$ value of $5.6788 \mu \mathrm{g} / \mathrm{ml}$. Similar result was reported on lemongrass and therefore our finding is in agreement with Cheel et al. 2005 and Lu et al. 2014. 


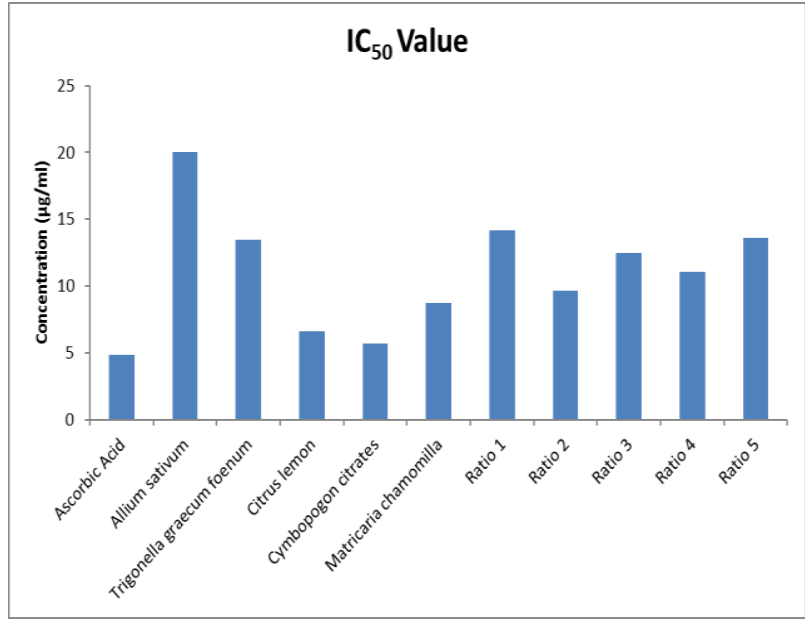

Fig 1: Comparison of $I_{50}$ value of antioxidant property of different plant extracts, oils and ratios.

\section{Minimum Inhibitory Concentration}

MIC of $25 \mathrm{mg} / \mathrm{ml}$ was shown by Trigonella foenum-graecum, Cymbopogon citratus and Matric ariachamomilla against the Staphylococcus aureus. MIC of $25 \mathrm{mg} / \mathrm{ml}$ was shown by Citrus lemon against Pseudomonas aeruginosa. Against Escherichia coli the best MIC $(50 \mathrm{mg} / \mathrm{ml})$ was shown by Cymbopogan citrates as compared to

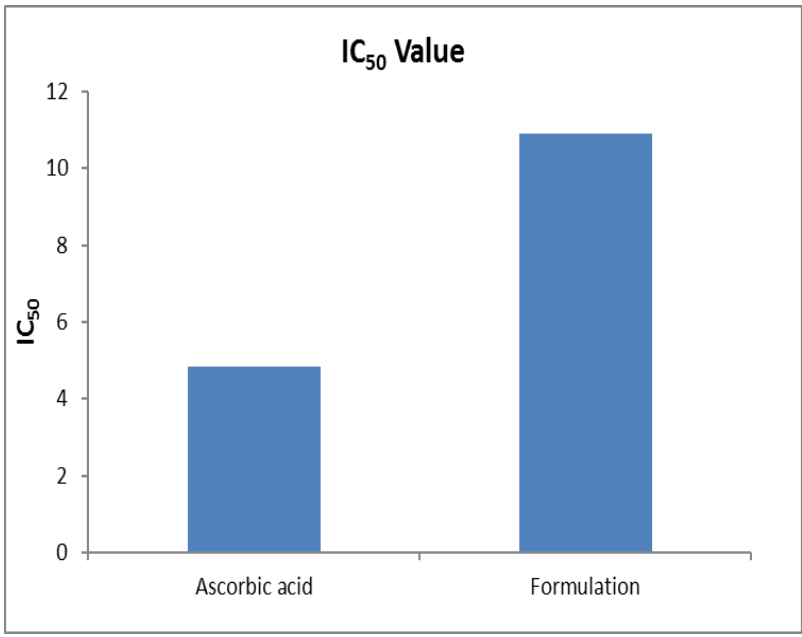

Fig. 2. Comparison of $I C_{50}$ value of Ascorbic acid and final formulation.

other extracts and essential oil. Against Klebsiella pneumonia all of the extracts and essential oils showed MIC of $100 \mathrm{mg} / \mathrm{ml}$ which is not very effective. Since lower MIC is indication of better antibacterial property, it was concluded that Citrus lemon is best antibacterial agent as compared to other extracts and oils which was followed by Cymbopogon citratus.

Table 4. MIC of plant extracts against different microorganism

\begin{tabular}{|c|c|c|c|c|}
\hline Plant extract & $\begin{array}{c}\text { Staphylococcus } \\
\text { aureus }\end{array}$ & $\begin{array}{c}\text { Pseudomonas } \\
\text { aeruginosa }\end{array}$ & Escherichia coli & $\begin{array}{c}\text { Klebsiella } \\
\text { pneumonia }\end{array}$ \\
\hline Trigonella foenum graceum & 25 & 25 & 100 & 100 \\
\hline Citrus lemon & 12.5 & 25 & 100 & 100 \\
\hline Matricaria chamomilla & 25 & 25 & 100 & 100 \\
\hline Cymbopogon citratus & 25 & 25 & 50 & 100 \\
\hline
\end{tabular}

\section{Formulation of lotion}

Thirteen tests were conducted as per the software. The three output variables (responses), such as viscosity (Y1), $\mathrm{pH}(\mathrm{Y} 2)$, spreadability (Y3), were evaluated. The effect of formulation variables on different dependent or response variables was assessed by the generated regression coefficients and $\mathrm{r}^{2}$ values. The fitted quadratic equations relating the responses such as viscosity (Y1), $\mathrm{pH}$ (Y2), spreadability (Y3), to the transformed factor are given in equation 1 to 3 respectively.

Table 5. Chemical composition of formulation in percentage

\begin{tabular}{llllllll}
\hline $\begin{array}{c}\text { Formulation } \\
\text { no. }\end{array}$ & $\begin{array}{c}\text { Stearic } \\
\text { Acid }\end{array}$ & $\begin{array}{c}\text { Cetostearyl } \\
\text { alcohol }\end{array}$ & Lanolin & $\begin{array}{c}\text { Mineral } \\
\text { oil }\end{array}$ & TEA & $\begin{array}{c}\text { Propylene } \\
\text { glycol }\end{array}$ & Water \\
\hline F1 & 10 & 1.21 & 9.75 & 12.19 & 3 & 1.21 & Qs to $100 \mathrm{ml}$ \\
F2 & 10 & 1.21 & 9.75 & 12.19 & 3 & 1.21 & Qs to $100 \mathrm{ml}$ \\
F3 & 5 & 1.21 & 9.75 & 12.19 & 4 & 1.21 & Qs to $100 \mathrm{ml}$ \\
F4 & 17.07 & 1.21 & 9.75 & 12.19 & 3 & 1.21 & Qs to $100 \mathrm{ml}$
\end{tabular}




\begin{tabular}{llllllll} 
F5 & 15 & 1.21 & 9.75 & 12.19 & 2 & 1.21 & Qs to $100 \mathrm{ml}$ \\
F6 & 15 & 1.21 & 9.75 & 12.19 & 4 & 1.21 & Qs to $100 \mathrm{ml}$ \\
F7 & 10 & 1.21 & 9.75 & 12.19 & 4.41 & 1.21 & Qs to $100 \mathrm{ml}$ \\
F8 & 10 & 1.21 & 9.75 & 12.19 & 3 & 1.21 & Qs to $100 \mathrm{ml}$ \\
F9 & 2.92 & 1.21 & 9.75 & 12.19 & 3 & 1.21 & Qs to $100 \mathrm{ml}$ \\
F10 & 10 & 1.21 & 9.75 & 12.19 & 3 & 1.21 & Qs to $100 \mathrm{ml}$ \\
F11 & 10 & 1.21 & 9.75 & 12.19 & 1.58 & 1.21 & Qs to $100 \mathrm{ml}$ \\
F12 & 10 & 1.21 & 9.75 & 12.19 & 3 & 1.21 & Qs to $100 \mathrm{ml}$ \\
F13 & 5 & 1.21 & 9.75 & 12.19 & 2 & 1.21 & Qs to $100 \mathrm{ml}$ \\
\hline
\end{tabular}

Note: Active plant extracts and essential oils combination was $5 \%$ in the formulation composition.

\section{Effect of independent variables on lotions}

\section{Effect on viscosity of lotion}

It was observed that Triethanolamine have negative effect on the viscosity whereas, the stearic acid have positive effect on the viscosity. The increase in the concentration of Triethanolamine decreases viscosity and the increase in concentration of stearic acid increase the viscosity.
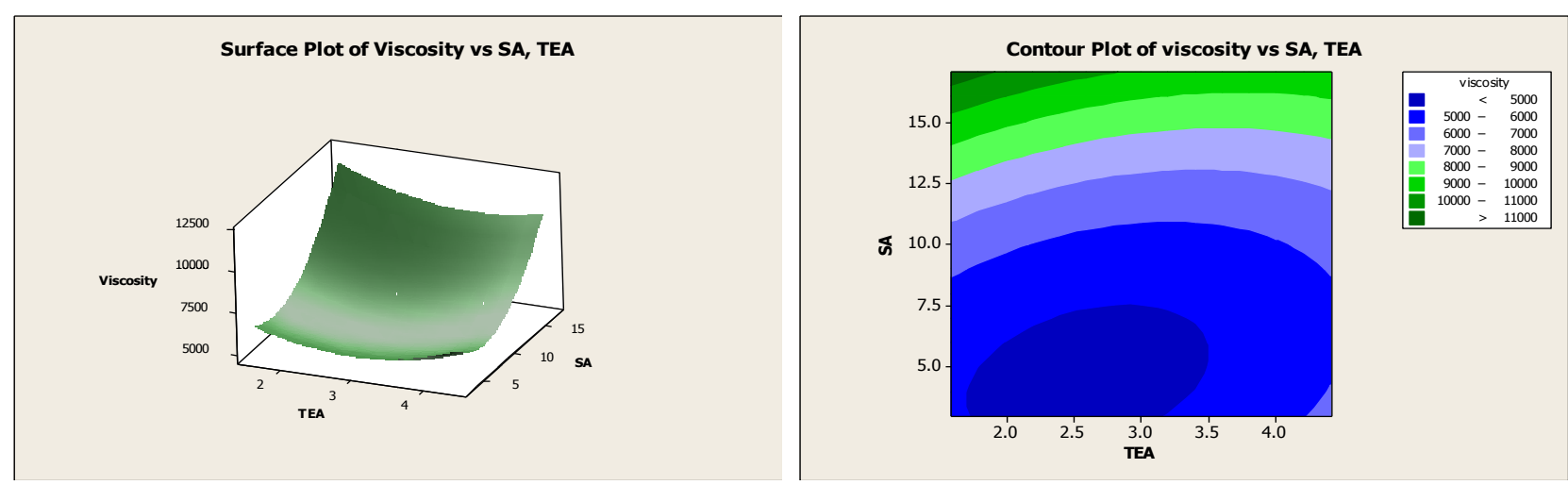

Fig. 3. Estimated contour plot and response surface plot elucidating the relationship between the viscosity and the independent variables (Triethanolamine and stearic acid).

\section{Effect on pH of lotion}

The positive magnitude of the coefficient of Triethanolamine represents the positive effect between the Triethanolamine and the $\mathrm{pH}$. The increase in concentration of Triethanolamine leads to the increase in the $\mathrm{pH}$ of the formulation.
Similarly, the negative magnitude of the coefficient of stearic acid denoted the inverse relation between the $\mathrm{pH}$ of the formulation and the stearic acid. The increase in concentration of stearic acid causes the decrease of the $\mathrm{pH}$ of the formulation.

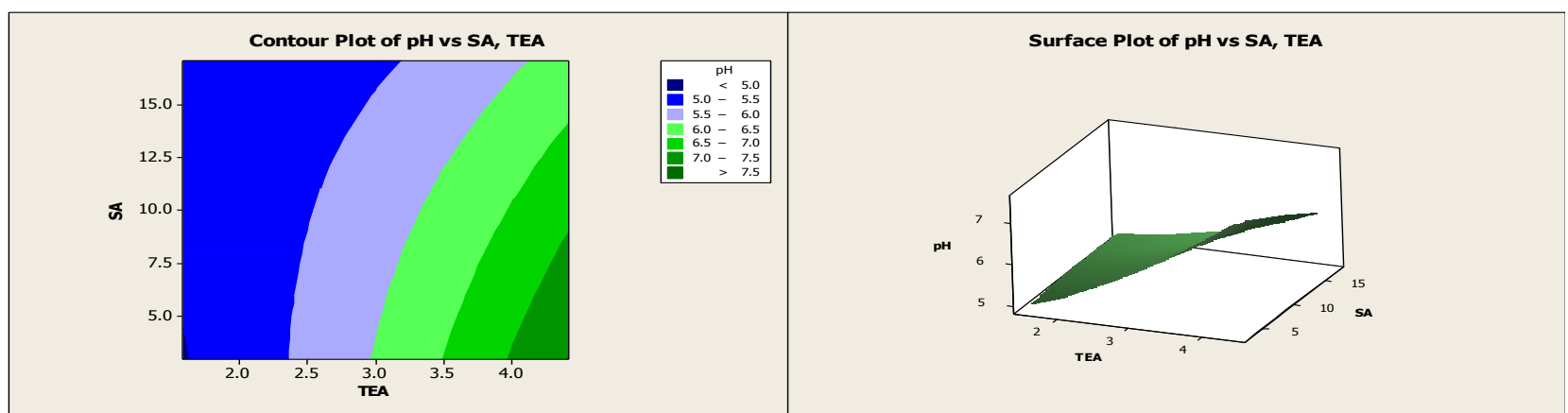

Fig. 4. Estimated contour plot and response surface plot elucidating the relationship between the pH and the independent variables (Triethanolamine and stearic acid). 


\section{Effect on spreadability of lotion}

Triethanolamine have positive effect so the increase in concentration of Triethanolamine increases the spreadability of lotion. In contrast, as the concentration of stearic acid increases the spreadability of the lotion decreases. The positive coefficient value of Triethanolamine indicated the increase in spreadability as the concentration of Triethanolamine increases.
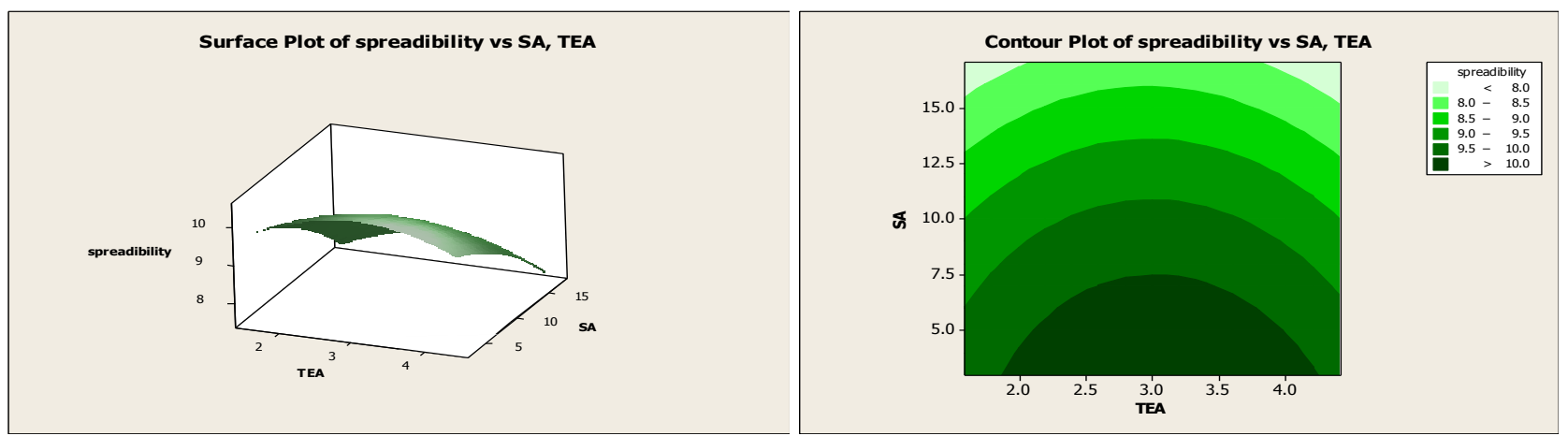

Fig. 5. Estimated contour plot and response surface plot elucidating the relationship between the spreadability and the independent variables (Triethanolamine and stearic acid).

Evaluation of pharmaceutical parameters of lotions

The $\mathrm{pH}$ of the lotion was within the limit which indicated that the lotion is safe to use for skin and is stable. The $\mathrm{pH}$ of lotion influences the stability. The stability of lotion increases with an increase in viscosity of the medium. Among thirteen different formulations the value of viscosity differed from $4908 \mathrm{cps}$ to $10187 \mathrm{cps}$. The range of spreadability for lotion was from 7 to $13 \mathrm{~cm}$. The measured minimum spread diameter of the lotion was $8.2 \mathrm{~cm}$ and the maximum spread diameter was $10.3 \mathrm{~cm}$.

Table 6. Value of Viscosity, $\mathrm{pH}$ and spreadability obtained for 13 different formulations

\begin{tabular}{|l|l|l|l|}
\hline Formulation & $\mathrm{pH}(4-7)$ & Viscosity $(<10000) \mathrm{cps}$ & Spreadibility $(7-13) \mathrm{cm}$ \\
\hline F1 & 5.57 & 5962 & 9.3 \\
\hline F2 & 5.74 & 5681 & 9.7 \\
\hline F3 & 7.02 & 5013 & 10.2 \\
\hline F4 & 5.41 & 10187 & 8.2 \\
\hline F5 & 5.13 & 9236 & 8.4 \\
\hline F6 & 6.19 & 7572 & 8.5 \\
\hline F7 & 6.78 & 6925 & 8.8 \\
\hline F8 & 5.5 & 5829 & 9.5 \\
\hline F9 & 5.96 & 4908 & 10.3 \\
\hline F10 & 6.01 & 5439 & 9.8 \\
\hline F11 & 5.11 & 6178 & 9 \\
\hline F12 & 6.05 & 5372 & 9.9 \\
\hline F13 & 5.25 & 5214 & 10 \\
\hline
\end{tabular}

The lotion was not irritating to the skin and it was water removable. The final appearance of lotion was found to be yellowish white in color. Emulsion formed during the formulation of lotion was evaluated for the type of emulsion. Oil miscible dye Sudan III was mixed with the sample and observed under microscope. Small red droplets of oil can be observed surrounded by water phase. This helps to 
identify that the lotion was oil-in water emulsion. The formed lotion was oil-in water type.

\section{Optimization of formulation}

The range of $\mathrm{pH}$ suitable for hand lotion was 4 to 7 and for spreadability the desired range was 7 to 13 $\mathrm{cm}$. The viscosity should be such that the lotion can be easily spread over the skin surface. The optimized formulation was evaluated for the response parameters and the value $\mathrm{pH}$ of optimized formulation was 5.6, value of viscosity was 5561 cps and the value of spreadability was 9.8. All the three parameters were within the limit and suitable for application over the skin.

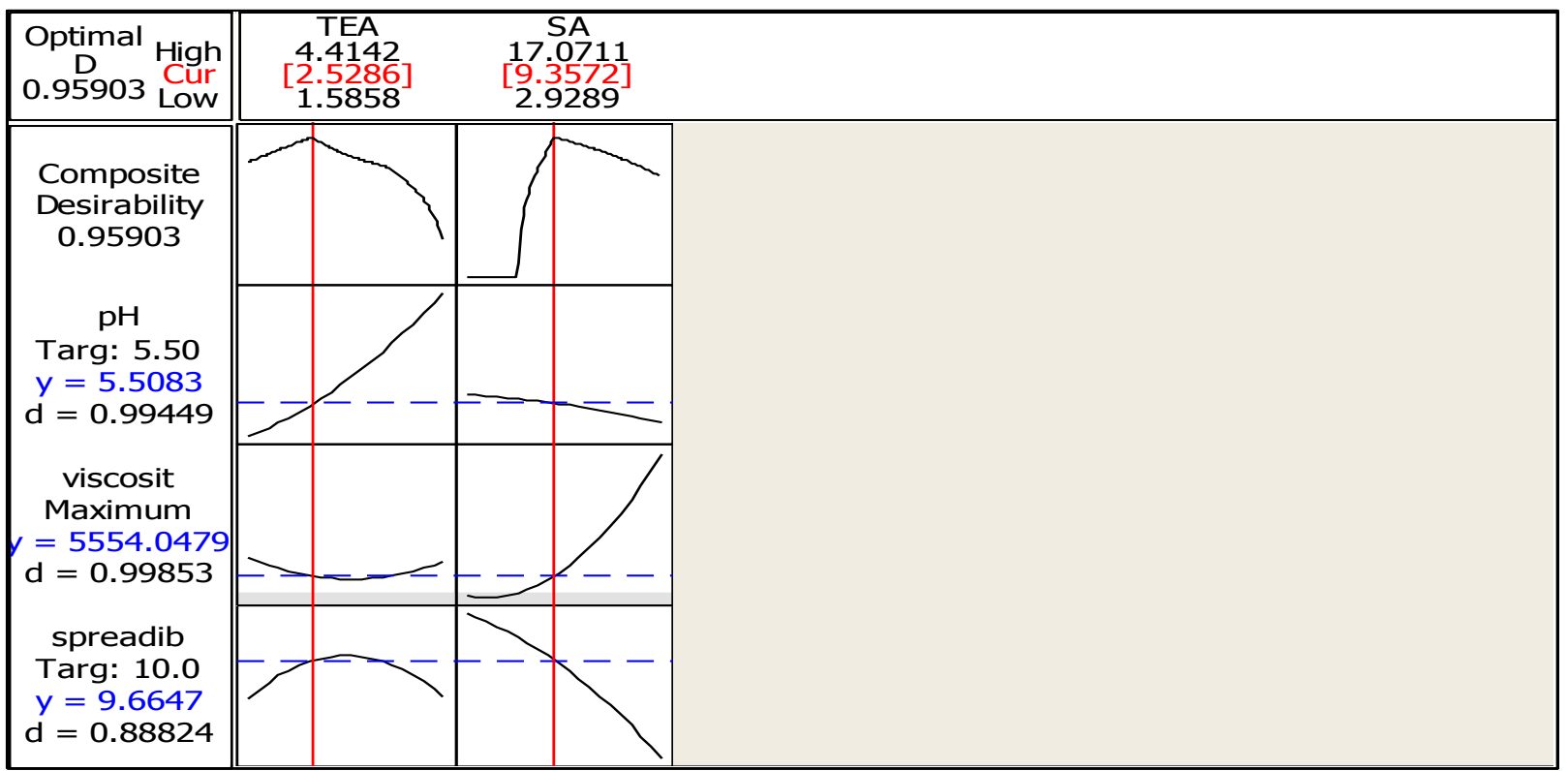

Fig. 6. Response Optimization plot.

The desirability results showed (2.52:9.35) ratio of Triethanolamine and Stearic acid as optimum. So, on the basis of the ratio obtained from the software final optimized formulation was developed.

\section{Stability test}

The stability test of final optimized lotion was carried out and it was found that the lotion was stable in room temperature and accelerated temperature for at least three months. The value of $\mathrm{pH}$, viscosity and spreadability all lay within the required range. There was no major difference in values of $\mathrm{pH}$, viscosity and spreadability as compared to the initial value.

Table 7. Stability test at room temperature and accelerated temperature (of optimized formulation)

\begin{tabular}{llllllll}
\hline Parameters & Initial value & \multicolumn{2}{l}{$\begin{array}{l}\text { Room temperature } \\
(25 \pm 2)^{\circ} \mathrm{C}\end{array}$} & \multicolumn{3}{l}{$\begin{array}{l}\text { Accelerated temperature } \\
(40 \pm 2)^{\circ} \mathrm{C} / 75 \% \mathrm{RH}\end{array}$} \\
\cline { 3 - 7 } & & 1 month & 2 month & 3 month & 1 month & 2 month & 3 month \\
\hline Viscosity & $5561 \mathrm{cps}$ & $5554 \mathrm{cps}$ & $5565 \mathrm{cps}$ & $5559 \mathrm{cps}$ & 5550 & 5564 & 5571 \\
$\mathrm{pH}$ & 5.6 & 5.7 & 5.9 & 5.8 & 5.8 & 5.9 & 6.1 \\
Spreadability & $9.8 \mathrm{~cm}$ & $9.6 \mathrm{~cm}$ & $9.9 \mathrm{~cm}$ & $9.7 \mathrm{~cm}$ & $9.6 \mathrm{~cm}$ & $9.9 \mathrm{~cm}$ & $10.0 \mathrm{~cm}$ \\
\hline
\end{tabular}

\section{CONCLUSION}

Oil in water type lotion was formulated using formulation of Trigonella foenum-graecum, Citrus lemon, Matricaria chamomilla and Cymbopogon citratus at the ratio of $1: 1: 1: 2$. This optimum formulation was designed with 2.52:9.35 ratios of triethanolamine and stearic acid. The lotion formulation showed no redness, edema, inflammation and irritation during sensitivity test indicating it is safe to use. By combining the 
different plant extracts it is possible to improve as well as synergize the cosmetic properties of prepared products compare to individual extracts. From the above study it has been revealed that that the lotion was stable in room temperature and accelerated temperature for at least three months.

\section{REFERENCES}

Buhse, L., Kolinski, R., Westenberger, B., Wokovich, A., Spencer, J., Chen, C. W., et al. 2005. Tropical drugs classification. International Journal of Pharmaceutics 295:101-112.

Cheel, J., Theoduloz, C., Rodriäguez, J. and Hirschmann, S. G. 2005. Free Radical Scavengers and Antioxidants from Lemongrass (Cymbopogon citratus Stapf) Journal of Agriculture Food Chemistry 53: 2511-7.

Collins, C. H., Lynes, P. M. and Grange, J. M. 1995. Microbiological Methods (7th edition), Butter Wont-Heinemann Ltd., Britain pp. 175-190.

Draize, J., Woodard, G. and Calvery, H. 1944. Methods for the study of irritation and toxicity of substances applied topically to the skin and mucus membranes. Journal of Pharmacology and experimental Therapeutics 82: 377-390.

Garg, A., Aggrawal, D., Garg, S. and Singla, A. K. 2002. Spreading of Semisolid Formulation an update. Pharmaceutical Technology 84:102.

Gediya, S. K., Mistry, R. B., Patel, U. K., Blessy, M. and Jain, H. N. 2011. Herbal plants: used as a cosmetics. Journal of Natural Product and Plant Resources 1:24-32.

Idson, B. and Lazarus, J. 1987. "Semisolids" The Theory and Practice of Industrial Pharmacy. In: L Lachman, HA Lieberman and JL Kanigs (eds) $2^{\text {nd }}$ edition, Philadelphia, PA, pp.215-244.

Junaid, S. A., Olabode, A. O., Onwuliri, F. C., Okwori, A. E. J. and Agina, S. E. 2006. The antimicrobial properties of Ocimum gratissimum gastrointestinal isolates. African Journal of Biotechnology 5 (22):2315-2321.

Kumar, K. K., Sasikanth, K., Sabareesh, M. and Dorababu, N. 2011. Formulation and
Evaluation of Diacerin Cream. Asian Journal Pharmaceutical Clinical Research 4(2):9398.

Lu, Y., Khoo, T. J. and Wiart, C. 2014. Antioxidant activity determination of citronellal and crude extracts of Cymbopogon citratus by three different methods. Pharmacology and Pharmacy 5: 395-400.

Mhatre, J., Nagaral, S. and Kulkarni S. 2014. Formulation and evaluation of antibacterial activity of a herbal ointment prepared from crude extracts of Aegle marmelos. International Journal of Pharmacy and Pharmaceutical Sciences 6(2):575-579.

Namita and Nimisha. 2013. Development and evaluation of herbal cosmeceutical for skin care. International Journal of Pharmacological and Biological Sciences 4(2):86-92.

Neuwald, F. 1966. Rheological studies of new cream bases with the Brookfield Synchroelectric viscometer, Journal of the society of cosmetic Chemists. 17: 213-233.

Negi, A., Sharma, N. and Singh, M.F. 2012. Formulation and Evaluation of an Herbal Anti-Inflammatory Gel Containing Eupatorium Leaves Extract. Journal of Pharmacognosy and Phytochemistry 1(4):112-117.

Ojala, T., Remes, S., Haansuu, P., Vuorela, H., Hiltunen, R. and Haahtela, K. 2000. Antimicrobial activity of some coumarin containing herbal plant growing in Finland. Journal of ethnopharmacology 73:299-305

Shivanand, P., Nilam, M. and Viral, D. 2010. Herbs play an important role in the field of cosmetics. International Journal of PharmTech Research 2: 632-639.

Tamburic S et al. 1996. A Comparison of Electrical and Rheological techniques for the Characterization of Creams.International Journal of Pharmacy 137: 243-248

Tharwat, F. Tadros. 2013. Emulsion Formation, Stability and Rheology, first edition, WlieyVCH Verlag GmbH and Co.KGaA, Germany

Trease, G. E. and Evans, W. C. 1989 Pharmacognosy.13th (ed). ELBS/Bailliere Tindall, London. Pp.345-6, 535-6, 772-3. 